\title{
Economic Conditions and SSI Applications
}

Austin Nichols, Lucie Schmidt, and Purvi Sevak

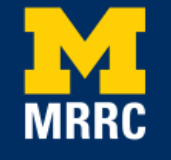

Project \#: UM12-20 


\title{
Economic Conditions and SSI Applications
}

\author{
Austin Nichols \\ Urban Institute and DeBruce Foundation \\ Lucie Schmidt \\ Williams College \\ Purvi Sevak \\ Hunter College \\ December 2014
Michigan Retirement Research Center
University of Michigan
P.O. Box 1248
Ann Arbor, MI 48104
www.mrrc.isr.umich.edu
(734) 615-0422

\section{Acknowledgements}

This work was supported by a grant from the Social Security Administration through the Michigan Retirement Research Center (Grant \# 5 RRC08098401-04-00). The findings and conclusions expressed are solely those of the authors and do not represent the views of the Social Security Administration, any agency of the Federal government, or the Michigan Retirement Research Center. 


\title{
Economic Conditions and SSI Applications
}

\begin{abstract}
The Supplemental Security Income (SSI) program provides federally-funded income support for individuals with disabilities, and has become one of the most important means-tested transfer programs in the United States. Previous studies have examined the effects of economic conditions on growth in disability caseloads, but most focus on the Social Security Disability Insurance (SSDI) program. Most work on SSI dates from before welfare reform, which had both direct and indirect effects on the composition of the population at risk for SSI participation. In this paper we examine the relationship between SSI application risk and economic conditions between 1996 and 2010, using data from the Survey of Income and Program Participation (SIPP) linked to the Social Security Administration's 831 file, which includes monthly data on SSI (and SSDI) application and receipt. Results from hazard models suggest that higher state unemployment rates have a large, positive effect on the risk of SSI application among jobless individuals, and our evidence suggests that female potential applicants may be more responsive to local economic conditions than men. State-level TANF policies have no effect on SSI application risk but state fiscal distress significantly increases application risk. Given the continued growth of the SSI program, understanding these relationships is increasingly important and policy-relevant.
\end{abstract}

\section{Citation}

Nichols, Austin, Schmidt, Lucie, and Sevak, Purvi. 2014. "Economic Conditions and SSI Applications.” University of Michigan Retirement Research Center (MRRC) Working Paper, WP 2014-318. Ann Arbor, MI. http://www.mrrc.isr.umich.edu/publications/papers/pdf/wp318.pdf

\section{Authors’ Acknowledgements}

We are grateful for funding from the Michigan Retirement Research Center, assistance in preparing the data from Stephan Lindner, and assistance in accessing the data from Thuy Ho, Francouse Becker, Tom Solomon, and Richard Chard at the U.S. Social Security Administration (SSA). The research reported herein was performed pursuant to a grant from the U.S. Social Security Administration (SSA) funded as part of the Retirement Research Consortium. The opinions and conclusions expressed are solely those of the author(s) and do not represent the opinions or policy of SSA or any agency of the Federal Government. Corresponding author: lschmidt@williams.edu; Department of Economics, Schapiro Hall, Williams College, Williamstown, MA 01267 


\section{Introduction}

Over the past 30 years, the Social Security Administration’s Supplemental Security Income (SSI) program, which provides federally-funded income support for disabled individuals, has become one of the most important means-tested cash aid programs in the United States. In 2009, SSI provided benefits to 4.5 million low-income adults who met its disability criteria. These numbers represent an 82 percent increase in the adult SSI caseload since 1990. In 2009, the Federal government spent \$37.7 billion on payments to SSI recipients, representing a 127 percent increase in real dollars since 1990.

A number of previous studies have looked at the effects of economic conditions on growth in disability caseloads. However, much of this work has focused on the Social Security Disability Insurance (SSDI) program, which is limited to those with a sufficient work history, who may be more responsive to economic conditions. Most research focusing specifically on SSI dates from the pre-welfare reform era. The welfare reform legislation passed in 1996 had both direct and indirect effects on SSI participation (Schmidt, 2004), and work by Wamhoff and Wiseman (2005/06) suggests that “a significant proportion of each year’s SSI awards to disabled non-elderly people [now] go to TANF [Temporary Assistance for Needy Families] recipients.” Understanding how the effects of economic conditions on SSI participation might have changed given this change in the composition of the population "at risk" is particularly important.

In this paper, we examine the relationship between SSI applications and economic conditions between 1996 and 2010 using data from the Survey of Income and Program Participation (SIPP) linked to the Social Security Administration's 831 file, which includes monthly data on SSI (and SSDI) application and receipt. We estimate hazard models of SSI application risk, and find that SSI application risk increases significantly with higher state unemployment rates. The magnitude of this effect is large - suggesting that a one-percentage point increase in the state 
unemployment rate would lead to a 22-percent increase in the risk of applying for SSI. Those who began their unemployment spell in a time of high unemployment are less likely to apply for SSI, consistent with the idea that the characteristics of the pool of newly unemployed varies systematically with the business cycle. Our results suggest that female potential applicants may be more responsive to economic conditions than males.

Contrary to our expectations, differences in state TANF policies, such as the stringency of time limits, work exemptions, or sanctions, did not have statistically significant effects on the likelihood of SSI application risk. Neither did variables that affected the relative financial benefit of participating in SSI versus TANF. However, a measure of state fiscal distress was positively and significantly associated with SSI application risk, consistent with previous research suggesting that states experiencing distress may take actions that encourage their residents to seek benefits from federally-funded transfer programs.

\section{Background}

A fully federally funded cash assistance program for the poor, SSI provides means-tested cash assistance to the elderly, blind, and disabled. The majority of SSI funding is federal, but many states do supplement benefits with state funds. The SSI disability determination process is quite complicated and involves five stages through which applicants must progress in order to receive benefits. At the first stage, individuals must show that they are not involved in “substantial, gainful” economic activity. The second and third stages involve medical evaluations. Those with "non-severe” impairments or impairments that are not expected to end in death or last at least 12 months are denied in Stage 2, and those with extremely severe impairments are immediately allowed in Stage 3. Stages 4 and 5 consider capacity to work. Applicants who are able to work in jobs that they held in the past are denied in Stage 4, and applicants who, given their age, education, 
and work experience, are judged able to work in any type of employment in the economy are denied in Stage 5. $\quad$ Less than half of all SSI applicants are ultimately approved (Nadel et al., 2003/2004). SSI is one of two major U.S. programs targeted at individuals with disabilities. The Social Security Disability Insurance program (SSDI) provides benefits to workers with disabilities who are insured by their contributions to the Social Security system. The disability determination process for SSDI is the same as that for SSI. However, benefit eligibility requires a sufficient work history, and benefits are not means tested, but depend on individuals' earnings histories. SSDI is a larger program than SSI, and is growing more rapidly. In 2009, 7.8 million workers with disabilities received SSDI, an increase of 158 percent since 1990. Primarily because of the work history requirements, SSDI applicants and recipients are less economically disadvantaged than those who apply for and receive SSI benefits. SSDI applicants are older, more highly educated, and have more financial wealth than SSI applicants. They are also more likely to be male, white, non-Hispanic, and married (Bound et al., 2003). Many individuals are eligible for benefits from both SSI and SSDI. These "concurrent” beneficiaries have sufficient work histories to qualify for SSDI, but their benefit levels are low enough that they still qualify for SSI. Of all working-age beneficiaries in 2004, 53 percent were SSDI only, 31 percent were SSI only, and 16 percent were concurrent.

While the disability determination process is stringent, there are a number of reasons to think that SSI participation may depend on macroeconomic conditions. First, the SSI means-testing process examines family income, so if other members of the family face decreases in income due to the business cycle, this could lead to increases in eligibility. In addition, there is evidence that suggests that rates of self-reported disabilities endogenously respond to the relative costs and benefits of disability program participation (Waidmann et al., 1995). As labor market opportunities decline, SSI participation becomes relatively more attractive.

\footnotetext{
${ }^{1}$ As noted by Chen and van der Klaauw (2008), this creates discontinuities in eligibility determination by age beginning at the age of 45 .
} 
A number of studies have looked at the effects of economic conditions on growth in disability caseloads, often focused on the SSDI program. Autor and Duggan (2003) find that shifts in state-level labor demand predict changes in SSDI participation. Black et al. (2002) exploit changes in coal prices as a shock to local earnings growth to examine effects of earnings on disability program participation. They find that both SSDI and SSI participation respond to earnings shocks, but that SSI participation is less responsive than that of SSDI. Stapleton and coauthors (Rupp and Stapleton, 1995; Stapleton et al., 1998; Stapleton et al., 1999) find that increased unemployment rates associated with the recession of the early 1990s played an important role in the growth of applications and awards during the pre-welfare reform years, but that the unemployment rate has a stronger effect on applications than on awards.

However, papers by Garrett and Glied (2000), Schmidt and Sevak (2004), Schmidt (2013), and Rutledge and Wu (2013) find that unemployment rates are negatively associated with the stock of SSI caseloads after controlling for state- and year-fixed effects. One possible explanation for this counterintuitive finding is that the dependent variables used in these analyses represent the stock of individuals on the SSI program, but economic conditions should affect transfer program rolls primarily through the flow of individuals onto and off of the program (for example, see Grogger, 2003 and Klerman and Haider, 2004). Since for many recipients SSI is an absorbing state, this suggests the importance of looking directly at application rates with longitudinal data.

In addition, most of the research on SSI participation focuses on the era before passage of major welfare reform in 1996. Welfare reform increased both individual- and state-level incentives to shift recipients from Aid to Families with Dependent Children (AFDC)/TANF to SSI. From the state’s perspective, because SSI is fully federally funded, whereas AFDC was funded by a matching grant, there have always been state-level fiscal incentives for moving recipients from AFDC to SSI. The Personal Responsibility and Work Opportunity Reconciliation Act of 1996 (PRWORA) strengthened these incentives by replacing AFDC's matching grants with fixed TANF block grants. 
At the individual level, monthly SSI benefits were always larger than AFDC benefits in most states. Because TANF benefits have tended to be constant in nominal terms, whereas SSI benefits are indexed each year to the inflation rate, the benefit differential between the two programs has widened. According to Wamhoff and Wiseman (2005/2006), by 2003 an SSI award to an adult in a three-person TANF family would increase family income by 115.4 percent on average. Even without widening financial incentives, SSI is relatively more attractive post welfarereform, given that TANF has stringent work requirements, time limits, and sanctions for not complying with rules. There is also evidence that states and third parties have acted as intermediaries to assist individuals with the SSI application process (Bound et al., 1998; Livermore et al., 1998; Pavetti and Kauff, 2006).

Consistent with these changing incentives, the existing literature suggests substantial movement of single-parent families to SSI. Kubik (2003) has shown that states undergoing unexpected fiscal distress were more likely to show increases in SSI caseloads relative to their AFDC population during the 1990s. Stapleton et al. (2001/02) analyze matched data from the SIPP and SSA records, and find that the probability of an SSI application is 2.4 times larger for past AFDC recipients than for other SIPP respondents. They conclude that a large share of the increase in SSI participation among young women during the 1990s was due to members of AFDC families. Schmidt and Sevak (2004) find that state-level reforms implemented through welfare waivers in the early 1990s led to a 21.6 percent increase in the probability of SSI participation among singlemother families. The General Accounting Office (1997) examined former AFDC recipients in Iowa, Massachusetts, and Wisconsin who lost their eligibility under new state TANF regulations, and found that 12 percent of households who lost AFDC benefits subsequently began receiving SSI. Wamhoff and Wiseman (2005/06) document that in 2003, 16 percent of families receiving TANF included a child or adult SSI recipient, and that the monthly incidence of TANF-related SSI awards 
has gone up. Schmidt (2013) finds that welfare reform significantly increased SSI participation, and that state policies that sanctioned welfare recipients for noncompliance had positive and significant effects on the SSI caseload. In addition, Schmidt (2013) finds that welfare reform appears to have changed the relationship between SSI participation and unemployment rates, as the SSI program has become more cyclical in response to business cycles in the years following welfare reform for women and children, but not for men.

The research suggesting increasing use of SSI among former welfare recipients implies that the composition of potential SSI recipients has changed in important ways. Given these changes, it is important to reevaluate the relationship between local economic conditions, state-level differences in welfare policy, and SSI applications, and to understand how this varies by demographic characteristics.

\section{Data}

Our analysis relies on survey data from the Survey of Income and Program Participation (SIPP) matched to administrative data from the Social Security Administration. The SIPP is a nationally representative longitudinal survey that collects data on a number of topics including employment, demographics, income, and program participation. Monthly data are available for sample members for up to roughly three years. We use data from the 1996, 2001, 2004, and 2008 SIPP panels.

While researchers have also used other datasets to study SSI receipt, we chose the SIPP for a number of reasons. First, the monthly data in the SIPP make it easier to examine dynamics related to employment, unemployment, and program receipt. Second, and most importantly, the SIPP data may be matched to monthly SSA administrative data on SSI and DI application and receipt, afberita lengthy approval process. The administrative data allow us to observe date of application, 
whereas data in the SIPP alone would only allow us to code date of SSI receipt. SSA's 831 file records every application for DI or SSI, and most decisions on that application.

The major advantage of the 831 files merged onto the SIPP is that we can see the precise date of first application. Since applicants may wait five months or many years before receiving benefits, but must remain out of the labor force until their application is resolved, the date of first receipt of benefits is far less relevant for labor force decisions. Similarly, labor market conditions that affect aggregate rates of application also affect the timeliness with which state Disability Determination Services offices process claims, and therefore affect the average lag from first application to eventual receipt of benefits. Analysis that relies solely on administrative data is limited by not being able to observe nonapplicants, and by the limited demographic data on applicants. Research has shown that using matched administrative records in this fashion provides more accurate estimates of SSI participation and benefit amounts than the self-reported information in SIPP (Huynh, Rupp, and Sears, 2002). In addition to reducing measurement error, the linked administrative data allow us to observe whether an individual applies for SSI at any point over a longer time horizon. This is important because some individuals may not apply for SSI until after spending considerable time looking for new employment.

We limit our sample to individuals who were ages 20 to 59 and newly unemployed during the period in which they were observed in the SIPP panel. This allows us to focus our analysis solely on the subpopulation most directly affected by changing economic conditions, and to observe them from the first month in which their experience of a change in the labor market is likely to directly affect their propensity to apply for SSI. 


\section{Model Specification}

We examine the relationship between SSI application and economic conditions by estimating a series of discrete time hazard models of program application on the monthly unemployment rate in the state. These models are estimated among the sample described above, of individuals newly unemployed during the SIPP panel. We consider the fact that both current and lagged labor market conditions should be related to one's current employment status and risk of program application. To address this, we use two measures of the unemployment rate - the "contemporaneous" state unemployment rate in the observation month and the "baseline" unemployment rate in the month the unemployment spell began.

The contemporaneous measure captures an individual's perception of their chance of gaining employment. The baseline measure (while adjusting for contemporaneous state unemployment rate) captures differential selection into unemployment during periods of high and low unemployment. For example, during a period of very high unemployment, such as the recent "great recession,” the pool of unemployed individuals may have a greater number of individuals "higher up" in the employability or skill distribution. These individuals should be less likely to apply for SSI. Because the two unemployment rates are highly correlated with each other, it is important to include both, even if one is only interested in the relationship between the contemporaneous rate and SSI application.

We control for the maximum TANF benefit for a family of three, as well as state-level SSI supplements. These variables determine the relative monetary advantage of participating in one program versus another. In addition, there is currently a great deal of variation across states in their welfare policies. States vary in their policies on sanctioning recipients from the roles, on time limits, and on work requirements. We examine whether these specific features of state TANF 
policies are significantly associated with increases in SSI applications, by including control variables for strict sanction, strict time limits, and strict work requirement policies.

As described above, the existing state-level fiscal incentives for moving recipients from AFDC to SSI were strengthened when PRWORA replaced AFDC's matching grants with fixed TANF block grants. Work by Kubik (2003) has shown that states undergoing unexpected fiscal distress were more likely to show increases in child SSI caseloads relative to their AFDC population during the 1990s. We use Kubik’s fiscal distress measure (calculated from data collected from the National Association of State Budget Officers [NASBO]), and examine the effect of this measure on SSI applications. We expect that states with larger unanticipated fiscal shocks will be more likely to experience increases in SSI applications.

All models adjust for age in five-year bands, gender, race, educational attainment, as well as indicators for being married and being an immigrant. We also adjust for whether an individual had low income at the start of the unemployment spell (indicator is equal to one if the respondent's family income was less than twice the federal poverty level). All specifications include state fixed effects.

In our preferred specification, we also adjust for the duration of unemployment with a measure of the natural log of months of unemployment, and we control for time with an indicator for the SIPP panel (1996, 2001, 2004, or 2008). We separately estimate the hazard of application for SSI only, as well as the hazard of application for either SSI or SSDI (as reported in the 831 file). While the focus of this study is to estimate impacts on SSI applications, we estimate the hazard of applying for either SSI or SSDI because many of the applications are joint applications rather than SSI-only applications. People may apply for both, and then find out whether they are eligible for one or the other or both. 
We estimate these specifications on the full sample of unemployed individuals. We also estimate the hazard of SSI application separately by gender and by age group (older or younger than age 45) to test whether there are differences across subgroups in estimated effects on program application. We test for the robustness of our findings using a number of alternative specifications. These include specifications that control for time using year or month variables; use only the contemporaneous unemployment rate; and estimate the hazard using complementary log-log regression. We also specified the baseline hazard using a variety of functional forms, including duration dummies and calendar time dummies, or log duration (in number of months) combined with calendar time dummies, both of which produced very similar estimates for the main coefficients of interest.

\section{Results}

Table 1 provides summary statistics for the analysis sample. Most individual variables are measured in the month that an individual enters the sample. As described above, an individual enters the sample at risk for SSI application in the month they go from being employed to not employed, as reported in the SIPP. The sample is drawn from the four SIPP panels, with 20 to 30 percent coming from each panel between 1996 and 2008. The sample is not drawn evenly across the years due to variation in both the size of SIPP panels and in employment outflows. However, it allows us to study the relationship between state variables and SSI application during a 14 year period, from 1996 - 2010. The last period of SIPP data we use is 2010, although we observe SSI and SSDI applications after that date.

Fifty-six percent of sample members are female, and half were married in the period that they entered the sample. Thirteen percent of the sample is foreign-born. Respondents range in age from 20 to 59 with more at the younger end of this range. Roughly three-quarters are non-Hispanic Whites 
and 12 percent are Black. Ninety-one percent have graduated from high school and 62 percent attended college. Approximately one-third enters the sample with family income less than twice the federal poverty level. The sample statistics differ from comparable statistics for a nationally representative sample because of how we select the sample - it includes individuals who are originally observed to be employed and then lose employment during the SIPP panel.

In the bottom of the table, we report summary statistics for selected time varying variables across person-month records. About one out of a thousand apply for SSI and three out of a thousand apply for SSI or DI in a given month at risk. Our key variable of interest, the monthly state unemployment rate, has a mean of 5.9 percent. State policy variables are merged to the data by calendar month.

Table 2 presents coefficient estimates and z statistics from two hazard models of application for disability benefits, estimated on the full sample at risk. Column 1 presents results for SSI-only application. Individual characteristics are associated with SSI application risk in expected directions. The risk of application is lower for individuals who are married. There are no significant differences in SSI application risk by either gender or race/ethnicity. Those living in households with foreign-born individuals are significantly less likely to apply for SSI, which is unsurprising given post-1996 restrictions on immigrant receipt of SSI (Bitler and Hoynes, 2013). The risk of application falls consistently with education level, such that those with some college have the lowest risk, followed by high school graduates. Having baseline family income of less han twice the than twice the federal poverty level significantly increases the risk of SSI application.

The coefficient on the state unemployment rate in the current period is positive and statistically significant at the 10 percent level, suggesting that a higher current unemployment rate increases the risk of SSI application. The coefficient estimate implies that a one-percentage point increase in the unemployment rate would lead to a 0.202 increase in the natural log of the odds of 
SSI application. Given the mean monthly application rate of one in a thousand, this translates to a 22 percent increase in the probability of SSI application. ${ }^{2}$ The coefficient on the state unemployment rate at the beginning of the unemployment spell is negative, consistent with the theory that the pool of individuals unemployed in periods of higher unemployment may be more employable and thus at lower risk of SSI application. However, this coefficient is not statistically different from zero. The risk of SSI application falls with each additional month since losing employment.

The state policy variables largely have no significant effect on the hazard of SSI application. This is true for the variables that measure the relative pecuniary benefit of SSI versus TANF (SSI state supplements and maximum TANF benefits), as well as for other characteristics of state welfare programs like strict TANF time limits, sanctions, and work exemptions. A higher per capita unexpected deficit shock significantly increases the risk of SSI application, consistent with Kubik (2003).

Column 2 presents results for SSI or SSDI application. As noted above, many applications are joint applications, and a large share of beneficiaries receives benefits from both programs concurrently. Results follow a similar pattern to the SSI-only application hazard model presented in Column 1. Current unemployment rates are positively and significantly associated with the risk of SSI/SSDI application, while the unemployment rate at the beginning of the unemployment spell now has a negative and significant effect. Women are significantly less likely to apply for SSI/SSDI, which is consistent with them being less likely to have sufficient work history to qualify for SSDI, as well as with previous research on applications (Bound et al., 2003). The estimated

\footnotetext{
${ }^{2}$ A logit coefficient of 0.202 translates to an increase in odds of 22.38 percent; the increase in probability is very close for low baseline probabilities, but declines to zero as the baseline probability increases. For a baseline probability of one in a thousand, we can convert the coefficient to a marginal effect of a one-point increase in unemployment rate on the probability of application by adding the coefficient estimate (0.202) to the natural log of the baseline odds (-6.09675). then exponentiate the sum to get the revised odds, and back out the revised probability (0.001227), which 
effect of family income below two times the federal poverty line is much smaller, which is unsurprising given that SSDI, unlike SSI, is not a means-tested program.

Table 3 estimates the hazard of SSI application on subpopulations stratified by gender and age. Column 1 reprints our original results from Column 1 of Table 2. Columns 2 and 3 present results stratified by gender (women in Column 2, men in Column 3), and some interesting differences emerge. First, the effects of economic conditions on SSI application risk are stronger for women than men, as the significant positive coefficient for the overall sample is primarily driven by women. However, the diminishing effect of months since the unemployment spell started is also larger for women. The negative effect of married status on SSI application risk is driven entirely by the women in the sample - marital status has no significant effect on application risk for men. Conversely, the negative effect of foreign-born status on SSI application risk is much larger for the men in the sample than for the women, as is the negative effect of attending college. The hastening effect of family income below twice the poverty line is stronger for the men in the sample than for the women.

Columns 4 and 5 stratify by age, where Column 4 presents results for individuals aged 45 and older, and Column 5 presents results for those 20-45. The relationship between economic conditions and SSI application risk is larger for the older individuals in our sample than for those in prime working age. As noted above, the disability determination process does introduce discontinuities by age beginning at the age of 45, and Chen and van der Klaauw (2008) have shown these discontinuities to be associated with reduced labor supply. Being married reduces the risk of SSI application by more for the younger individuals than the older individuals, and the effects of low baseline family income are larger for the under 45 age group. However, the educational gradient in SSI risk is much stronger for the older individuals. For both subsample analyses, the effects of the unexpected deficit shock on SSI application risk are similar (between men and 
women, and between those older and younger than age 45). Consistent with the results from Table 2, most of the subsample analyses show no significant effects of the other state policy variables.

In Table 4, we present results from a number of alternate specifications to check the robustness of our findings on SSI application risk. These include controlling for time with year effects or with month effects; excluding the state-level unemployment rate at the start of the individual's unemployment spell from the specification; and using complementary log-log regression. Our results are largely similar in magnitude to the main results presented in Table 2; the results from the logit complementary log-log regression are effectively identical.

The results that stray the farthest from our original specification are in Column 3, where we exclude the baseline unemployment rate (i.e. the state-level unemployment rate at the start of the individual's employment spell). The coefficient on the current unemployment rate in this specification is about half the magnitude of our original specification. This drop-off in effect size is consistent with the possibility that the baseline unemployment rate is picking up unobserved variation in the composition of newly unemployed individuals. When it is excluded, the estimated coefficient on the contemporaneous unemployment rate is biased down.

\section{Conclusion}

Given the continued growth of the SSI program among both disabled adults and children, understanding how economic conditions affect program participation amidst changing SSI program composition has become increasingly important. Using data from the Survey of Income and Program Participation (SIPP) linked to the Social Security Adminstration's 831 file, we find that SSI application risk increases significantly with higher state unemployment rates. The magnitude of this effect is large - suggesting that a one-percentage point increase in the state unemployment rate would lead to a 22-percent increase in the risk of applying for SSI. Those who began their 
unemployment spell in a time of high unemployment are less likely to apply for SSI, consistent with the idea that the pool of the newly unemployed varies in characteristics with the business cycle. Our evidence suggests that female potential applicants may be more responsive to local economic conditions than men.

Contrary to our expectations, differences in state TANF policies, such as the stringency of time limits, work exemptions, or sanctions, did not have statistically significant effects on the likelihood of SSI application risk. Neither did variables that affected the relative financial benefit of participating in SSI versus TANF. However, a measure of state fiscal distress was positively and significantly associated with SSI application risk, suggesting that state cutbacks could drive up SSI applications.

Our results suggest the net benefits of federal aid during downturns may be underestimated. If federal interventions, such as the American Recovery and Reinvestment Act (ARRA) in 2009, result in reduced state unemployment rates, either by averting the laying off of state workers or by stimulating demand, the recession-induced increase in SSI and SSDI applications could be dampened. Our results also suggest it could be dampened if such aid relieves state fiscal distress. Future research should further examine the cyclical determinants of SSI application and the extent to which federal aid such as ARRA or extended unemployment benefits impact application risk. 


\section{References}

Autor, David H. and Mark G. Duggan. 2003. “The Rise in the Disability Rolls and the Decline in Unemployment.” Quarterly Journal of Economics 118(1).

Bitler, Marianne and Hilary Hoynes. 2013. “Immigrants, Welfare Reform, and the US Safety Net.” In Immigration, Poverty, and Socioeconomic Inequality, David Card and Steven Raphael, eds. New York: Russell Sage.

Black, Dan, Kermit Daniel, and Seth Sanders. 2002. “The Impact of Economic Conditions on Participation in Disability Programs: Evidence from the Coal Boom and Bust.” American Economic Review 92(1): 27-50.

Bound, John, Richard V. Burkhauser and Austin Nichols. 2003. "Tracking the Household Income of SSDI and SSI Applicants.” In Worker Well-Being and Public Policy: Research in Labor Economics, Solomon Polacheck, ed. Volume 22: 113-158.

Bound, John, Sherrie Kossoudji, and Gema Ricart-Moes. 1998. “The Ending of General Assistance and SSI Disability Growth in Michigan: A Case Study.” In Rupp and Stapleton, eds., Growth in Disability Benefits: Explanations and Policy Implications, pp 223-248.

Chen, Susan and Wilbert van der Klaauw. 2008. "The Work Disincentive Effects of the Disability Insurance Program in the 1990s.” Journal of Econometrics 142(2): 757-784

Garrett, Bowen and Sherry Glied. 2000. “Does State AFDC Generosity Affect Child SSI Participation?” Journal of Policy Analysis and Management 19(2): 275-95.

General Accounting Office. 1997. Welfare Reform: States’ Early Experiences with Benefit Termination. Report to the Committee on Finance, U.S. Senate, HEHS-97-74.

Grogger, Jeffrey. 2003. “The Effects of Time Limits, the EITC, and Other Policy Changes on Welfare Use, Work, and Income among Female-Headed Families.” Review of Economics and Statistics 85(2): 394-408.

Huynh, Minh, Kalman Rupp, and James Sears. 2002. The Assessment of Survey of Income and Program Participation (SIPP) Benefit Data Using Longitudinal Administrative Records, Office of Research, Evaluation, and Statistics, Social Security Administration.

Klerman, Jacob, and Steven J. Haider. 2004. "A Stock-Flow Analysis of the Welfare Caseload." Journal of Human Resources 39(4):865-886.

Kubik, Jeffrey D. 2003. "Fiscal Federalism and Welfare Policy: The Role of States in the Growth of Child SSI.” National Tax Journal 56(1): 61-79.

Kubik, Jeffrey D. 1999. "Incentives for the Identification and Treatment of Children with Disabilities: The Supplemental Security Income Program.” Journal of Public Economics 73(2): 187-215. 
Livermore, Gina, David C. Stapleton, and Andra Zeuschner. 1998. "Lessons from Case Studies of Recent Program Growth in Five States.” In Rupp and Stapleton, eds., Growth in Disability Benefits: Explanations and Policy Implications, pp 249-274.

Nadel, Mark, Steve Wamhoff, and Michael Wiseman. 2003/04. “Disability, Welfare Reform, and Supplemental Security Income.” Social Security Bulletin 65(3).

Pavetti, LaDonna A. and Jacqueline Kauff. 2006. "When Five Years is not Enough: Identifying and Addressing the Needs of Families Nearing the TANF Time Limit in Ramsey County, Minnesota.” Mathematica Policy Research.

Rupp, Kalman and David Stapleton. 1995. "Determinants of the Growth in the Social Security Administration’s Disability Programs.” Social Security Bulletin 58(4): 43-70.

Rutledge, Matthew S. and April Yanyuan Wu. 2013. "Why Do SSI and SNAP Enrollments Rise in Good Economic Times and in Bad?" Center for Retirement Research at Boston College Working Paper.

Schmidt, Lucie. 2013. “The New Safety Net? Supplemental Security Income after Welfare Reform.” Williams College Department of Economics Working Paper \#2013-07.

Schmidt, Lucie. 2004. "Effects of Welfare Reform on the Supplemental Security Income (SSI) Program.” National Poverty Center Policy Brief, \#4.

Schmidt, Lucie and Purvi Sevak. 2004. “AFDC, SSI, and Welfare Reform Aggressiveness: Caseload Reductions vs. Caseload Shifting,” Journal of Human Resources 39(3): 792-812.

Stapleton, David, David Wittenburg, Michael Fishman, and Gina Livermore. 2001/02.

“Transitions from AFDC to SSI Prior to Welfare Reform.” Social Security Bulletin 64(1).

Stapleton, David, Michael Fishman, Gina Livermore, and David Wittenburg. 1999. Policy Evaluation of the Overall Effects of Welfare Reform on SSA Programs: Final Report. Report prepared by the Lewin Group for the Social Security Administration.

Stapleton, David, Kevin A. Coleman, Kimberly A. Dietrich, and Gina A. Livermore. 1998. "Econometric Analyses of DI and SSI Application and Award Growth." In Rupp and Stapleton, eds., Growth in Disability Benefits: Explanations and Policy Implications, p 3192.

Waidmann, Timothy, John Bound, and Michael Schoenbaum. 1995. “The Illusion of Failure: Trends in the Self-Reported Health of the U.S. Elderly.” Milbank Quarterly 73(2): 253-88.

Wamhoff, Steve and Michael Wiseman. 2005/2006. “The TANF/SSI Connection.” Social Security Bulletin, 66(4): 21-35. 


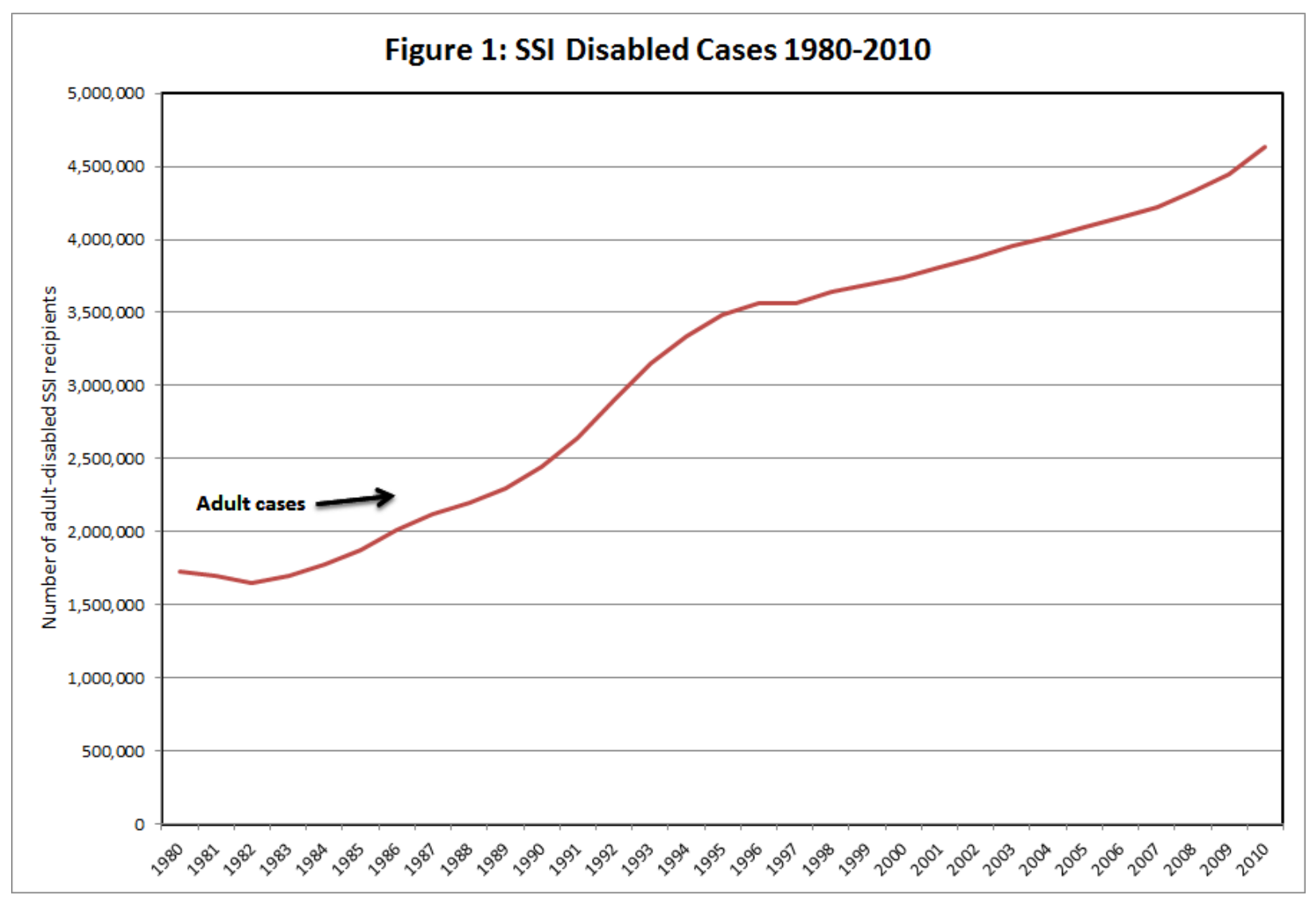

Source: Social Security Bulletin Annual Statistical Supplement, 2011 
Table 1. Characteristics of Sample Members in Month Respondent First Unemployed Std.

\begin{tabular}{lcr} 
& Mean & Dev \\
\cline { 2 - 3 } Baseline Characteristics $(n=26,077$ unique persons) \\
SIPP 1996 panel & 0.274 & 0.450 \\
SIPP 2001 panel & 0.209 & 0.406 \\
SIPP 2004 panel & 0.304 & 0.460 \\
SIPP 2008 panel & 0.213 & 0.410 \\
Foreign-born & 0.131 & 0.337 \\
Married & 0.505 & 0.500 \\
Female & 0.564 & 0.496 \\
Age 20-24 & 0.205 & 0.404 \\
Age 25-29 & 0.148 & 0.355 \\
Age 30-34 & 0.138 & 0.345 \\
Age 35-39 & 0.126 & 0.331 \\
Age 40-44 & 0.121 & 0.327 \\
Age 45-49 & 0.109 & 0.312 \\
Age 50-54 & 0.094 & 0.292 \\
Age 55-59 & 0.059 & 0.236 \\
White Non-Hispanic & 0.763 & 0.426 \\
Black & 0.124 & 0.330 \\
High school graduate & 0.914 & 0.281 \\
Attended college & 0.625 & 0.484 \\
Income less than 2*FPL & 0.351 & 0.477 \\
Monthly measures $(n=200,254$ person-months) \\
Applied for DI or SSI & 0.003 & 0.053 \\
Applied for SSI only & 0.001 & 0.039 \\
State unemployment rate & 5.934 & 2.263 \\
& & \\
& &
\end{tabular}


Table 2: Logistic Regression Results of Program Application Hazard

\begin{tabular}{|c|c|c|c|c|}
\hline & SSI Only & & SSI or SSDI & \\
\hline Contemporaneous state unemp. rate & $\begin{array}{l}0.202 \\
(1.81)\end{array}$ & $*$ & $\begin{array}{l}0.186 \\
(2.73)\end{array}$ & $* *$ \\
\hline $\begin{array}{l}\text { Baseline state unemployment rate (at start } \\
\text { of unemployment) }\end{array}$ & $\begin{array}{l}-0.127 \\
(-1.58)\end{array}$ & & $\begin{array}{l}-0.117 \\
(-2.49)\end{array}$ & $* *$ \\
\hline Log months since employed & $\begin{array}{c}-0.348 \\
(-4.8)\end{array}$ & $* *$ & $\begin{array}{l}-0.312 \\
(-5.92)\end{array}$ & $* *$ \\
\hline Maximum TANF benefit, family of 3 & $\begin{array}{l}0.219 \\
(0.72)\end{array}$ & & $\begin{array}{l}0.148 \\
(0.78)\end{array}$ & \\
\hline State SSI supplement, divided by 100 & $\begin{array}{l}-0.428 \\
(-0.79)\end{array}$ & & $\begin{array}{l}0.356 \\
(0.84)\end{array}$ & \\
\hline $\begin{array}{l}\text { Per capita unexpected deficit shock, } \\
\text { divided by } 1000\end{array}$ & $\begin{array}{c}2.362 \\
(2.6)\end{array}$ & $* *$ & $\begin{array}{l}1.317 \\
(2.1)\end{array}$ & $* *$ \\
\hline Strict TANF time limits & $\begin{array}{l}-0.299 \\
(-0.88)\end{array}$ & & $\begin{array}{l}0.058 \\
(0.21)\end{array}$ & \\
\hline Strict TANF sanctions & $\begin{array}{l}0.579 \\
(1.42)\end{array}$ & & $\begin{array}{l}0.153 \\
(0.55)\end{array}$ & \\
\hline Strict TANF work exemptions & $\begin{array}{l}-0.202 \\
(-0.75)\end{array}$ & & $\begin{array}{l}-0.241 \\
(-1.9)\end{array}$ & $*$ \\
\hline SIPP 2001 panel & $\begin{array}{l}-0.112 \\
(-0.44)\end{array}$ & & $\begin{array}{l}-0.085 \\
(-0.42)\end{array}$ & \\
\hline SIPP 2004 panel & $\begin{array}{l}-0.183 \\
(-0.69)\end{array}$ & & $\begin{array}{l}0.035 \\
(0.19)\end{array}$ & \\
\hline SIPP 2008 panel & $\begin{array}{l}-1.064 \\
(-1.53)\end{array}$ & & $\begin{array}{l}-0.783 \\
(-1.85)\end{array}$ & $*$ \\
\hline Foreign-born in $\mathrm{HH}$ & $\begin{array}{l}-1.054 \\
(-3.96)\end{array}$ & ** & $\begin{array}{l}-1.010 \\
(-3.07)\end{array}$ & $* *$ \\
\hline Married & $\begin{array}{l}-0.773 \\
(-3.83)\end{array}$ & $* *$ & $\begin{array}{c}-0.291 \\
(-1.9)\end{array}$ & $*$ \\
\hline Female & $\begin{array}{l}0.151 \\
(0.92)\end{array}$ & & $\begin{array}{l}-0.189 \\
(-1.83)\end{array}$ & $*$ \\
\hline Age $20-24$ & $\begin{array}{l}-1.433 \\
(-5.56)\end{array}$ & $* *$ & $\begin{array}{c}-2.529 \\
(-11.23)\end{array}$ & $* *$ \\
\hline Age 25-29 & $\begin{array}{l}-0.363 \\
(-0.78)\end{array}$ & & $\begin{array}{l}-1.310 \\
(-3.23)\end{array}$ & $* *$ \\
\hline Age 30-34 & $\begin{array}{l}-0.517 \\
(-1.68)\end{array}$ & * & $\begin{array}{l}-1.319 \\
(-6.59)\end{array}$ & $* *$ \\
\hline Age 35-39 & $\begin{array}{l}-0.171 \\
(-0.47)\end{array}$ & & $\begin{array}{l}-0.835 \\
(-5.01)\end{array}$ & $* *$ \\
\hline Age 40-44 & $\begin{array}{l}0.260 \\
(0.83)\end{array}$ & & $\begin{array}{l}-0.458 \\
(-2.62)\end{array}$ & $* *$ \\
\hline Age 45-49 & $\begin{array}{l}0.533 \\
(1.69)\end{array}$ & $*$ & $\begin{array}{c}-0.098 \\
(-0.6)\end{array}$ & \\
\hline Age 50-54 & 0.794 & $* *$ & 0.186 & \\
\hline
\end{tabular}




\begin{tabular}{|c|c|c|c|c|}
\hline & (3.88) & & $(1.42)$ & \\
\hline \multirow[t]{2}{*}{ White Non-Hispanic } & 0.177 & & -0.193 & \\
\hline & $(0.55)$ & & $(-1.00)$ & \\
\hline \multirow[t]{2}{*}{ Black } & 0.194 & & -0.077 & \\
\hline & $(0.5)$ & & $(-0.32)$ & \\
\hline \multirow[t]{2}{*}{ High school graduate } & -0.239 & $*$ & -0.243 & $*$ \\
\hline & $(-1.71)$ & & $(-1.66)$ & \\
\hline \multirow[t]{2}{*}{ Attended college } & -0.476 & $* *$ & -0.220 & $*$ \\
\hline & $(-2.37)$ & & $(-1.89)$ & \\
\hline \multirow[t]{2}{*}{ Baseline income $<2 * \mathrm{FPL}$} & 1.057 & $* *$ & 0.480 & $* *$ \\
\hline & $(6.32)$ & & $(4.04)$ & \\
\hline $\mathrm{N}$ & 193,450 & & 199,870 & \\
\hline
\end{tabular}


Table 3. Logistic Regressions of SSI Application Hazard, by Subpopulation

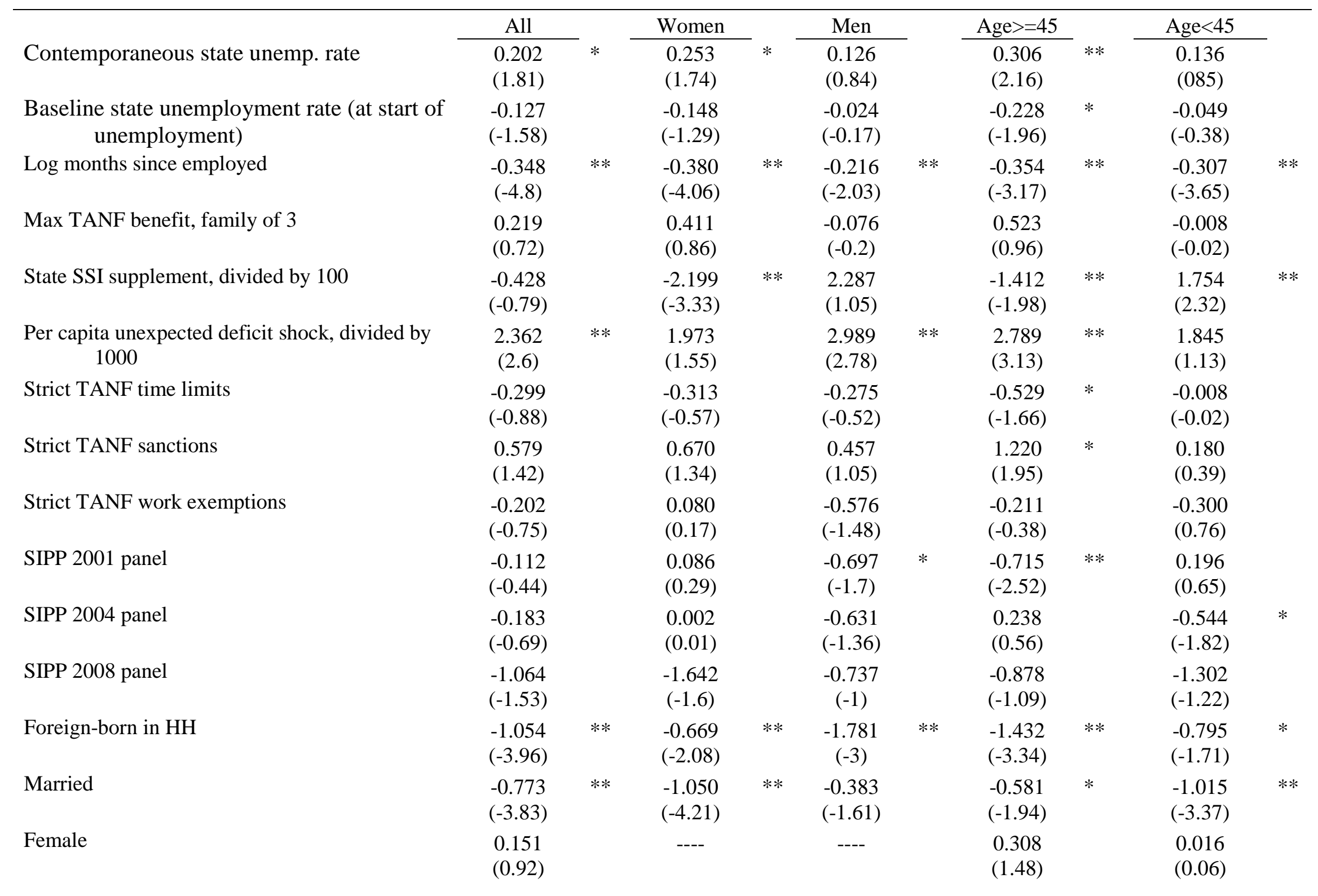


White Non-Hispanic

Black

High school graduate

Attended college

Baseline income $<2 *$ FPL

$\mathrm{N}$

\begin{tabular}{|c|c|c|c|c|c|c|c|c|}
\hline $\begin{array}{l}0.177 \\
(0.55)\end{array}$ & & $\begin{array}{l}0.453 \\
(1.31)\end{array}$ & & $\begin{array}{l}0.008 \\
(0.02)\end{array}$ & & $\begin{array}{l}-0.230 \\
(-0.6)\end{array}$ & & $\begin{array}{l}0.539 \\
(1.11)\end{array}$ \\
\hline $\begin{array}{c}0.194 \\
(0.5)\end{array}$ & & $\begin{array}{l}0.455 \\
(1.12)\end{array}$ & & $\begin{array}{l}0.073 \\
(0.16)\end{array}$ & & $\begin{array}{l}-0.118 \\
(-0.21)\end{array}$ & & $\begin{array}{l}0.428 \\
(0.91)\end{array}$ \\
\hline $\begin{array}{l}-0.239 \\
(-1.71)\end{array}$ & $*$ & $\begin{array}{l}-0.036 \\
(-0.15)\end{array}$ & & $\begin{array}{l}-0.524 \\
(-1.53)\end{array}$ & & $\begin{array}{l}-0.666 \\
(-2.53)\end{array}$ & $* *$ & $\begin{array}{l}0.108 \\
(0.50)\end{array}$ \\
\hline $\begin{array}{l}-0.476 \\
(-2.37)\end{array}$ & $* *$ & $\begin{array}{l}-0.574 \\
(-2.18)\end{array}$ & $* *$ & $\begin{array}{l}-0.393 \\
(-1.46)\end{array}$ & & $\begin{array}{l}-0.699 \\
(-3.07)\end{array}$ & $* *$ & $\begin{array}{l}-0.321 \\
(-1.28)\end{array}$ \\
\hline $\begin{array}{l}1.057 \\
(6.32)\end{array}$ & $* *$ & $\begin{array}{l}0.867 \\
(3.7)\end{array}$ & $* *$ & $\begin{array}{l}1.350 \\
(4.37)\end{array}$ & $* *$ & $\begin{array}{l}0.842 \\
(3.53)\end{array}$ & $* *$ & $\begin{array}{l}1.219 \\
(5.92)\end{array}$ \\
\hline 193,450 & & 122,766 & & 63,045 & & 59,245 & & 128,380 \\
\hline
\end{tabular}

Note: Regressions include state fixed effects, age group fixed effects, and a constant term. Z statistics are in parentheses.

** Denotes statistical significance at the $5 \%$ level and * at the $10 \%$ level. 
Table 4. Robustness Checks of Logistic Regressions of SSI Application Hazard

\begin{tabular}{|c|c|c|c|c|c|c|c|c|}
\hline & $\begin{array}{l}\text { Calendar } \\
\text { Year } \\
\text { Effects }\end{array}$ & & $\begin{array}{l}\text { Baseline } \\
\text { Hazard } \\
\text { Dummies }\end{array}$ & & $\begin{array}{c}\text { Excluding } \\
\text { Baseline } \\
\text { Unemployment } \\
\text { Rate } \\
\end{array}$ & & $\begin{array}{l}\text { Complementary } \\
\text { Log-Log } \\
\text { Regression }\end{array}$ & \\
\hline Contemporaneous state unemp. rate & $\begin{array}{l}0.168 \\
(1.61)\end{array}$ & & $\begin{array}{c}0.186 \\
(1.6)\end{array}$ & & $\begin{array}{l}0.108 \\
(1.14)\end{array}$ & & $\begin{array}{l}0.202 \\
(1.81)\end{array}$ & * \\
\hline $\begin{array}{l}\text { Baseline state unemployment rate (at start of } \\
\text { unemployment) }\end{array}$ & $\begin{array}{l}-0.142 \\
(-1.71)\end{array}$ & $*$ & $\begin{array}{l}-0.113 \\
(-1.38)\end{array}$ & & --- & & $\begin{array}{l}-0.127 \\
(-1.58)\end{array}$ & \\
\hline Max TANF benefit, family of 3 & $\begin{array}{l}0.121 \\
(0.35)\end{array}$ & & $\begin{array}{l}0.211 \\
(0.7)\end{array}$ & & $\begin{array}{l}0.225 \\
(0.74)\end{array}$ & & $\begin{array}{l}0.218 \\
(0.72)\end{array}$ & \\
\hline State SSI supplement, divided by 100 & $\begin{array}{l}-0.380 \\
(-0.7)\end{array}$ & & $\begin{array}{l}-0.419 \\
(-0.76)\end{array}$ & & $\begin{array}{l}-0.371 \\
(-0.68)\end{array}$ & & $\begin{array}{c}-0.430 \\
(-0.8)\end{array}$ & \\
\hline Per capita unexpected deficit shock, divided by 1000 & $\begin{array}{l}2.050 \\
(2.41)\end{array}$ & $* *$ & $\begin{array}{l}2.338 \\
(2.62)\end{array}$ & $* *$ & $\begin{array}{l}2.382 \\
(2.61)\end{array}$ & $* *$ & $\begin{array}{l}2.363 \\
(2.59)\end{array}$ & $* *$ \\
\hline Strict TANF time limits & $\begin{array}{l}-0.185 \\
(-0.52)\end{array}$ & & $\begin{array}{l}-0.306 \\
(-0.89)\end{array}$ & & $\begin{array}{l}-0.328 \\
(-0.98)\end{array}$ & & $\begin{array}{l}-0.299 \\
(-0.88)\end{array}$ & \\
\hline Strict TANF sanctions & $\begin{array}{l}0.577 \\
(1.46)\end{array}$ & & $\begin{array}{l}0.572 \\
(1.42)\end{array}$ & & $\begin{array}{l}0.578 \\
(1.42)\end{array}$ & & $\begin{array}{l}0.580 \\
(1.42)\end{array}$ & \\
\hline Strict TANF work exemptions & $\begin{array}{l}-0.009 \\
(-0.03)\end{array}$ & & $\begin{array}{l}-0.187 \\
(-0.71)\end{array}$ & & $\begin{array}{l}-0.200 \\
(-0.75)\end{array}$ & & $\begin{array}{l}-0.200 \\
(-0.75)\end{array}$ & \\
\hline $\begin{array}{l}\mathrm{N} \\
\text { Note: Regressions include state dummies, a constant } t \\
\text { Z statistics are in parentheses. }{ }^{* *} \text { Denotes statistical } \mathrm{s}\end{array}$ & $\begin{array}{l}193,450 \\
\text { all variabl } \\
\text { ce at the } 50\end{array}$ & & $\begin{array}{l}193,450 \\
\text { in Table } 2 \\
\text { ind * at the }\end{array}$ & & $\begin{array}{l}193,450 \\
\text { vel. }\end{array}$ & & 193,450 & \\
\hline
\end{tabular}

